\title{
EVALUATION OF IN UTERO EXPOSURE TO ARSENIC IN SOUTH AFRICA
}

Halina B. Röllin ${ }^{1,2, ¥}$, Kalavati Channa ${ }^{3}$, Bukola G. Olutola ${ }^{1}$, Jon $\varnothing$. Odland ${ }^{1,4}$

${ }^{1}$ School of Health Systems and Public Health, Faculty of Health Sciences, University of Pretoria, Pretoria, South Africa

${ }^{2}$ Environment and Health Research Unit, Medical Research Council, Johannesburg, South Africa

${ }^{3}$ Lancet Laboratories, Department of Analytical Chemistry, Johannesburg, South Africa

${ }^{4}$ Institute of Community Medicine, University of Troms $\varnothing$, Troms $\varnothing$, Norway

$¥$ Corresponding author at the University of Pretoria, Private Bag X323, Pretoria 0001, South Africa. Tel: +27 12354 2080;

Email addresses: $\underline{\text { Halina.Rollin@up.ac.za and hrollin@mrc.ac.za }}$ 


\section{Abstract}

Early life exposure to inorganic arsenic (iAs) has been shown to interfere with foetal and early childhood development, and is associated with morbidity and mortality in adulthood. The purpose of this study was to evaluate exposure to As in utero, to determine the association between maternal and cord blood of As and birth outcomes in South African populations. Total arsenic was measured in maternal blood of a total cohort $(n=650)$ and in paired cord blood and urine of a subset cohort $(n=317)$. Overall, the geometric mean (GM) of As in maternal blood was $0.62 \mu \mathrm{g} / \mathrm{L}(\mathrm{n}=650 ; 95 \% \mathrm{CI}, 0.58-0.66)$. In the subset cohort, the GM of maternal blood As was $0.96 \mu \mathrm{g} / \mathrm{L}(\mathrm{n}=350$; 95\% CI, 0.91-1.02); in paired cord blood, the GM was $0.78 \mu \mathrm{g} / \mathrm{L}(\mathrm{n}=317 ; 95 \% \mathrm{CI}, 0.74-0.83)$; and in urine (creatinine-corrected), the GM was $14.26 \mu \mathrm{g} / \mathrm{g}$ creatinine $(\mathrm{n}=317 ; 95 \% \mathrm{CI}, 12.64-16.09)$. A linear correlation was found between $\log$ maternal blood As and $\log$ cord blood As (rho=0.80, $\mathrm{p}<0.001$ ). Birth outcomes showed geographical differences. in gestational age $(\mathrm{p}<0.001)$, birth length $(\mathrm{p}=0.019)$, head circumference $(\mathrm{p}<0.001)$, Apgar score at 5 min $(\mathrm{p}<0.001)$ and parity $(\mathrm{p}<0.002)$. In a multivariate analysis, no association between maternal blood (AsB) levels and birth outcomes were found. However, the lower the gestational age, the higher the levels of maternal AsB ( $\beta$ $=-0.054 ; 95 \%$ CI-0.087 to -0.020$)$ and mothers who had had at least one child were less likely to have higher AsB if compared to those who had never had any child $(\beta=-0.177$; 95CI-0.322 to 0.031$)$.

In both univariate and multivariate analyses, being single, and drinking water from communal outdoor taps, boreholes and rivers resulted-was associated with higher As levels. The findings suggest that more research is needed to evaluate the impact of low level As exposure on postnatal development. 
Keywords: arsenic, biological monitoring, in utero exposure, placental transfer, birth outcomes, arsenic sources

\section{Introduction}

It has been shown that exposure to arsenic (As) during pregnancy can have detrimental effects on foetal development, birth outcomes and early childhood development. Pregnant women and the population in general may be exposed to As through ingestion of food and drinking water, inhalation, and dermally, following contact with industrially contaminated soil and water and from naturally occurring contamination. In some geographical regions, mainly in Bangladesh, Taiwan and India, the major source of As is drinking well water which contains naturally occurring As concentrations many times exceeding the World Health Organization (WHO) guideline of $10 \mu \mathrm{g} / \mathrm{L}$ (Ahuja S.:, 2008; IARC Monograph, 2012). It has been estimated that more than 100 million people worldwide rely on As-contaminated well water as the source of their drinking water (Fangstrom et al., 2009). In these areas, water is a primary contributor of exposure to As. In Bangladesh, it has been shown that cooked rice is also a significant source of population exposure (Bae et al., 2002). Similarly, GilbertDiamond et al., 2011 has reported that rice consumption contributed to exposure of US women to arsenic (Gilbert-Diamond et al., 2011). In areas where water As concentration is low, food and smoking are thought to be the primary contributors (Dictor, 2004) .

Chemically, As is classified as a metalloid that exists naturally in the environment, both in inorganic and organic forms and in different oxidation states, each exerting potentially different toxic effects in humans (Marchiset-Ferlay et al., 2012). Arsenic is classified as a carcinogen and neurotoxicant by the IARC and the National Research Council (IARC Monograph, 2012; NRC, 2001). The main effects of As poisoning via drinking water are cancerous and non-cancerous skin lesions evident as hyperpigmentation and keratosis of the palms and feet (CHEN and WU, 1962). In endemic areas, an increase in primary cancers of the skin, lung, bladder and kidney have been observed. Some chronic diseases such as 
peripheral and cardiovascular diseases, neurological disorders, diabetes and hypertension are also thought to be associated with exposure to As (Abhyankar et al., 2012; De Vizcaya-Ruiz et al., 2009; Rahman et al., 2009a; Rahman et al., 2009b; States et al., 2009).

Some studies have examined the effect of high As exposure in pregnancy and the respective birth outcomes, both in animal models and in humans. Research indicates that pregnancy can alter the metabolism efficiency of inorganic As but this association is not yet well understood (Gebel, 2000; Kapaj et al., 2006; Vahter and Concha, 2001). This effect of As will depend on the dose and exposure duration, genetic and nutritional status, but also on co-exposure to other toxicants (Gebel, 2000). In animals, it has been shown that high doses of As have negative effects on the developing foetus (Golub et al., 1998). Similarly, in humans, reduction in birth weight, as well as increase in spontaneous abortions and infant mortality associated with As exposure have been observed (Ahmad et al., 2001; Hopenhayn et al., 2003; Huyck et al., 2007; Rahman et al., 2007; von Ehrenstein et al., 2007) . Recently, Farzan et al., reported that in utero As exposure was associated with an increased risk of infections requiring medical treatment during the first year of life, particularly diarrhoea and respiratory symptoms (Farzan et al., 2016). In addition to inorganic As crossing into the human placenta and accumulating in the developing foetus, it also accumulates in the placenta disrupting its normal function, potentially resulting in lower birth weight at term, shorter birth length and smaller head and chest circumference (Ahmad et al., 2001; Concha et al., 1998; Laine et al., 2015; Rahman et al., 2009a; Tabacova et al., 1994). Thus, toxic effects of exposure to high levels of As $(>10 \mu \mathrm{g} / \mathrm{L})$ via drinking of contaminated water are well defined, health effects caused by exposure to low levels of As present in water and the diet are not clear (Rahman et al., 2009b). Studies from Chile, Argentina and Europe have reported similar disorders following exposures to much lower concentrations of As in drinking water, varying between undetectable levels and $3.6 \mu \mathrm{g} / \mathrm{L}$ (Hopenhayn et al., 2003; Rahman et al., 
2009b; States et al., 2009). More recently, Farzan et al., 2013 have linked early-life As exposure to an increased risk of cancer in adulthood (Farzan et al., 2013).

To date, research investigating health effects of low level As exposure have produced conflicting results (Fei et al., 2013; Guan et al., 2012; Thomas et al., 2015), indicating the need for more research into the possible toxicity of As at low, long-term exposures, particularly in women of reproductive age and their offspring/babies (Rahman et al., 2009b).

In South Africa and other African countries the main sources of As originate from mining and related industries, as well as agricultural operations. However, there is a lack of information on natural levels of As in drinking water and soils. Smedley et al., 1996 has documented groundwater contamination with As in the Obuasi gold mining area of Ghana (Smedley et al., 1996) and Sami and Druzynski (2003) have examined geological occurrence of As in selected areas of South Africa. Nationwide, where 200 boreholes of 1514 boreholes sampled for As have been found to contain arsenic concentrations above WHO standards (Kempster PL. et al., 2007; Sami K. and Druzynski AL., 2006).

The aim of this study was to assess in utero exposure to total As, as measured in maternal blood at delivery, and to examine the possible impact of As exposure on birth outcomes in populations residing along the Indian and Atlantic Oceans in South Africa. In a paired mother-child sub-cohort, the research team also assessed the association between maternal and cord blood and evaluated the correlation between As levels in three biological parameters, viz. maternal blood and maternal urine at delivery, and cord blood post-partum. Possible gender response to in utero As exposure was also examined.

\section{Materials and methods}

\subsection{Study sites and participants}


Five sites were included in the study: three sites (Sites 1 to 3 ) were situated along the Indian Ocean coast, and two sites (Sites 4 and 5) were situated along the Atlantic Ocean coast of South Africa. All study sites were rural, except for the city of Cape Town site (Site 4). Potential study candidates were recruited among women who were admitted for delivery at the local maternity sections at public hospitals. After the objectives of the study were explained, women who agreed to participate signed an informed consent form and agreed to donate blood and urine before delivery, and to the collection of cord blood after delivery. Participants agreed to answer a socio-demographic questionnaire which also included the topics of diet, lifestyle, and self-reported health status. The dietary part of the questionnaire recorded the frequency of intake of various basic foods during pregnancy. Participants also consented to access and use of hospital birth outcome data (including maternal and neonate characteristics such as weight, length and head circumference, gestational age, as well as birth complications, if any) for research purposes. In total, 650 women answered the questionnaire and donated pre-partum blood samples. Due to financial constraints, the collection of additional samples (pre-partum urine samples $(n=316)$ and post-partum cord blood samples $(\mathrm{n}=317)$ was limited to women residing in Sites 1 to 3, which formed the subcohort of this study, along the Indian Ocean coast.

\subsection{Sampling collection}

A sterile venoject system was used for all blood collections. From each woman, a volume of $10 \mathrm{ml}$ of venous blood was collected before delivery into a BD Vacutainer tube $(10 \mathrm{ml}$ capacity and containing EDTA). Participants from the sub-cohort also donated $30 \mathrm{ml}$ of urine before delivery. Umbilical cord blood $(10 \mathrm{ml})$ was collected post-partum by a nursing sister using a syringe. 


\subsection{Sample processing and analytical procedures}

The analyses for total As content in whole blood (AsB) and urine (AsU) were performed using an Inductively Coupled Plasma-Mass Spectrometer (ICP-MS) instrument (Agilent 7500ce ICP-MS with an Octopole Reaction System). Only total As was measured in this study, As speciation measurements were not performed. Contamination-free vessels and procedures were used throughout, and validation of results was accomplished by including certified standards, as well as certified references quality controls, in the analyses.

Briefly, the whole blood samples $(0.5 \mathrm{ml}$ volumes $)$ were digested with $1 \mathrm{ml}$ nitric acid (Fluka, Trace Select Ultra for trace analysis) at $90^{\circ} \mathrm{C}$ for 2 hours. After cooling, the internal standard was added and samples were diluted with water to a final volume of $7 \mathrm{ml}$. Arsenic was measured in 'Helium' acquisition mode with ${ }^{72} \mathrm{Ge}$ as the internal standard. Aliquots of each sample were analysed in triplicate. For quality assurance, two certified reference controls, viz. Seronorm ${ }^{\mathrm{TM}}$ Trace Elements (Sero LTD., Billingstad, Norway) in whole blood (Levels 1 and 2), were analysed with every analytical run, at intervals between every 10 samples. Urine samples ( $1 \mathrm{ml}$ volumes $)$ were digested with $0.1 \mathrm{ml}$ of $65 \%$ ultrapure nitric acid (Fluka, Trace Select Ultra for trace analysis). An internal standard solution containing ${ }^{72} \mathrm{Ge},{ }^{115} \mathrm{In}$ and ${ }^{197} \mathrm{Au}$ was added $(50 \mu \mathrm{l})$ to all samples, reagent blanks, reference controls and calibration standards and made up to $5 \mathrm{ml}$ (5 times sample dilution). Urinary As (AsU) levels were measured in 'Helium' acquisition mode. The percentage recovery, when using certified standards (Seronorm Urine Blank and Lyphochek Level 1 and 2), was 95.1\% and 97.6\% for level 1 and 2, respectively.

The detection limits (three times the standard deviation of all blank samples) for AsB was $0.13 \mu \mathrm{g} / \mathrm{L}$, and for AsU, $0.11 \mu \mathrm{g} / \mathrm{L}$. Creatinine levels were measured using a 'Cobas Mira' Analyser.

The sample analyses were conducted by the South African National Institute for Occupational Health (NIOH) laboratory, which participates in the Wadsworth Center - New 
York State Department of Health Proficiency testing scheme for whole blood and urine. The results obtained are consistently accepted with no indication of bias.

\subsection{Subjects information}

Covariate information was obtained during the questionnaire-based interview and from medical records. Maternal weight and height were recorded at the hospital on admission. From the medical records, the following newborn characteristics were retrieved: birth weight (grams), birth length $(\mathrm{cm})$, head circumference $(\mathrm{cm})$ and gestational age (weeks). Pre-term labour was defined as mothers giving birth at less than 37 weeks gestational age. Education was categorised as no education, completed primary school, completed secondary school and any level of tertiary education reached. Maternal tobacco smoking was defined as ever or never. Exposure to environmental tobacco smoke (ETS) was defined as exposure to tobacco smoke from smoking by others in the household. A binary classification was used for exposure to indoor smoke from the burning of wood and coal separating participants using electricity. Dietary questions relating to the intake of protein, carbohydrates, dairy products, tea, coffee, bottled water, fruits, as well as vine, root and leafy vegetables, were assessed and classified as daily, at least once a week and seldom (both for pre-pregnancy and during pregnancy).

\subsection{Statistical analyses}

The statistical analyses were performed using STATA (StataCorp, 2013. Stata Statistical Software: Release 13. College Station, TX: StataCorp LP). Statistical analyses using the chisquare test, Wilcoxon rank sum (Mann Whitney) and Kruskal-Wallis rank tests were performed as appropriate across all the study sites. In cases where As concentration was equal to or below the limit of detection (LOD) of the method, and for statistical purposes, these concentrations were set at $0.5 \times$ LOD (Croghan, 2003). The distribution of As levels in maternal blood and urine and in cord blood, were skewed and were log transformed. 
Bivariate analyses between As exposure, sizes at birth and covariates were evaluated by Spearman's correlation coefficient. Predictors were divided into socio-demographics, nutrition, maternal anthropometry measures, infant anthropometry measures, tobacco use and exposure to second-hand smoking based on findings from the literature (See Introduction) (Seber and Lee, 2003).

Multiple linear regression was carried out using a backward deletion approach, starting with a full model of factors significantly associated with natural logarithm-transformed maternal blood As levels at a $10 \%$ level of significance in the univariate analysis. Statistical significance was then set at $\mathrm{p}<0.05$ for the final model. Multicollinearity was tested using Variance Inflation Factor (VIF) and none of the VIFs was above 10, the rule of thumb for multicollinearity. The association between maternal blood AsB level and obstetric and neonatal characterictics in the absence of socio-economic, environmental and nutritional variables was also investigated.

\subsection{Ethical considerations}

Ethics approval for the study was obtained from the Human Research Ethics Committee of the University of Witwatersrand in Johannesburg (Protocol no. M10742), and from the relevant provincial Departments of Health. The sites along the Indian Ocean coast (Sites 1 to 3) fall under the Provincial Department of Health of KwaZulu Natal, which issued ethical consent for each site and requested the CEOs of the respective hospitals to allow this research to take place. Each CEO confirmed that he/she allowed the research work to proceed. The sites along the Atlantic Ocean coast (Sites 4 and 5) fall under the Western Cape Provincial Department of Health; identical procedures were followed in terms of obtaining consent for the study. Confidentiality was maintained by assigning identification numbers to all study 
participants. During the informed consent process, it was emphasised that participation was voluntary and could be withdrawn at any time.

\section{Results}

\subsection{Characteristics of the study population}

The population characteristics specified by the geographic position (namely the Indian and Atlantic Ocean) and the type of residential areas (namely rural or urban), are presented in Table 1. Of the total study cohort $(n=650), 350$ participants resided along the Indian Ocean coast, and 300 participants along the Atlantic Ocean coast of South Africa. Of the total study cohort ( $\mathrm{n}=650), 450$ women $(69 \%)$ resided in rural areas, and 200 women $(31 \%)$ in an urban area. Population characteristics among the five groups under study were significantly different. Ethnicity for most of the participants was African Black, with $45 \%$ of the women residing along the Atlantic Ocean coast being Coloured. Women from the Indian Ocean sites were significantly younger than those from the Atlantic Ocean sites $(p=0.015)$. The proportion of mothers who were married at the time of the interview was higher in the Atlantic area than the Indian Ocean $(35.8 \%$ vs. $12.1 \%$; $<<0.001)$.

Along the Indian Ocean sites, more than a third (41\%) of the subjects had attained tertiary education level, compared to only $18 \%$ from the Atlantic Ocean sites. Collectively, the large majority of participants was unemployed, but-with a significantly lower proportion of unemployed women at the Atlantic Ocean sites $(\mathrm{p}<0.001)$. The majority of the participants lived in formal housing (74\%) owned by them or family members, but in the Atlantic Ocean sites, more than $19 \%$ of participants were living in informal dwellings (shacks).

Table 1. Population characteristics for the total cohort, Indian Ocean and Atlantic Ocean population and individual study sites

\begin{tabular}{|l|c|c|c|c|c|c|c|c|c|}
\hline Characteristic & Total & Indian & Atlantic & p-value & Indian & Indian & Indian & Atlantic & Atla \\
\hline
\end{tabular}




\begin{tabular}{|c|c|c|c|c|c|c|c|c|c|}
\hline & $(n=650)$ & $\begin{array}{c}\text { Ocean } \\
(n=350)\end{array}$ & $\begin{array}{c}\text { Ocean } \\
(n=300)\end{array}$ & & $\begin{array}{c}\text { Ocean } \\
\text { Site 1 } \\
\text { (Rural) } \\
(n=100)\end{array}$ & $\begin{array}{c}\text { Ocean } \\
\text { Site } 2 \\
\text { (Rural) } \\
(n=200)\end{array}$ & $\begin{array}{l}\text { Ocean } \\
\text { Site } 3 \\
\text { (Rural) } \\
(n=50)\end{array}$ & $\begin{array}{c}\text { Ocean } \\
\text { Site } 4 \\
\text { (Urban) } \\
\text { (n=200) }\end{array}$ & $\begin{array}{l}\text { Oc } \\
\text { Sit } \\
\text { (Ru } \\
\text { ln= }\end{array}$ \\
\hline \multicolumn{10}{|l|}{ Maternal characteristics } \\
\hline Age (years) (mean, SD) & $25.2(6.2)$ & $24.5(6.3)$ & $26.1(6.0)$ & $<0.001$ & $23.8(6.8)$ & $24.6(6.0)$ & $25.6(6.4)$ & $26.1(6.3)$ & 26.0 \\
\hline Marital status (n, \%) & & & & $<0.001$ & & & & & \\
\hline Married & $146(23.1)$ & $41(12.1)$ & $105(35.8)$ & & $37(37.0)$ & $47(24.5)$ & $7(14.0)$ & 114(57.9) & $53(5$ \\
\hline Single & $375(59.2)$ & $249(73.2)$ & $126(43.0)$ & & $63(63.0)$ & $143(74.5)$ & $43(86.0)$ & $81(41.1)$ & $45(4$ \\
\hline Living together & $112(17.7)$ & $50(14.7)$ & $62(21.2)$ & & $32(32.0)$ & $17(9.0)$ & $1(2.0)$ & $41(21.0)$ & $21(2$ \\
\hline Education (n, \%) & & & & $<0.001$ & & & & & \\
\hline None/Primary & $54(8.6)$ & $50(15.2)$ & $4(1.35)$ & & $23(26.1)$ & $23(12.1)$ & $4(8.0)$ & $2(1.0)$ & $2(2.0$ \\
\hline Secondary & $403(64.5)$ & $154(47.0)$ & $249(83.8)$ & & $31(35.2)$ & $103(54.2)$ & $20(40.0)$ & 180(91.4) & $69(6$ \\
\hline Tertiary & $168(26.9)$ & $124(37.8)$ & $44(14.8)$ & & $34(38.6)$ & $64(33.7)$ & $26(52.0)$ & 15(7.6) & $29(2$ \\
\hline $\begin{array}{l}\text { Percentage } \\
\text { unemployed }(n, \%)\end{array}$ & 483(75.9) & $294(86.0)$ & $189(64.3)$ & $<0.001$ & $94(94.0)$ & $156(81.3)$ & $44(88.0)$ & $122(62.2)$ & $67(6$ \\
\hline $\begin{array}{l}\text { Ownership of home } \\
(\mathrm{n}, \%)\end{array}$ & & & & $<0.001$ & & & & & \\
\hline Owned & $531(83.1)$ & $324(94.2)$ & $207(70.2)$ & & $100(100)$ & $180(92.8)$ & $44(88.0)$ & 135(69.2) & $72(7$ \\
\hline Rented & $108(16.9)$ & $20(5.8)$ & $88(29.8)$ & & 0(0) & $14(7.2)$ & $6(12.0)$ & $60(30.8)$ & $28(2$ \\
\hline Housing type (n, \%) & & & & $<0.001$ & & & & & \\
\hline Formal housing & $472(74.0)$ & $285(83.3)$ & $187(63.2)$ & & 91(91.0) & $163(84.5)$ & $31(63.3)$ & $111(56.6)$ & $76(7$ \\
\hline Flat & $33(5.2)$ & $12(3.5)$ & $21(7.1)$ & & $0(0)$ & $12(6.2)$ & $0(0)$ & $20(10.2)$ & $1(1.0$ \\
\hline Backyard dwelling & $27(4.2)$ & $3(0.9)$ & $24(8.1)$ & & $0(0)$ & $2(1.0)$ & $1(2.0)$ & 18(9.2) & $6(6.0$ \\
\hline Informal housing & $84(13.2)$ & $26(7.6)$ & $58(19.6)$ & & $7(7.0)$ & $16(8.3)$ & $3(6.1)$ & $41(20.9)$ & $17(1$ \\
\hline Other & $22(3.5)$ & $16(4.7)$ & $6(2.0)$ & & $2(2.0)$ & $0(0)$ & $14(28.6)$ & $6(3.1)$ & $0(0)$ \\
\hline Race/ethnicity (n,\%) & & & & $<0.001$ & & & & & \\
\hline African black & 498(78.4) & $338(98.8)$ & $160(54.6)$ & & $100(100)$ & 190(98.5) & 49(98) & 115(59.6) & $45(4$ \\
\hline Coloured & $128(20.2)$ & $0(0.0)$ & $128(43.7)$ & & $0(0)$ & $0(0)$ & $0(0)$ & $77(39.9)$ & $51(5$ \\
\hline Other & $9(1.4)$ & $4(1.2)$ & $5(1.7)$ & & $0(0)$ & $3(1.2)$ & $1(2.0)$ & $1(0.5)$ & $4(4.0$ \\
\hline $\begin{array}{l}\text { Fuel use for cooking } \\
(n, \%)\end{array}$ & & & & $<0.001$ & & & & & \\
\hline Electricity & $479(74.7)$ & $195(56.7)$ & $284(95.6)$ & & $15(15.0)$ & $145(74.5)$ & $35(70.0)$ & 192(97.5) & $92(9$ \\
\hline Paraffin & $34(5.3)$ & $26(7.5)$ & $8(2.7)$ & & $0(0)$ & $24(12.4)$ & $2(4.0)$ & $3(1.5)$ & $5(5.0$ \\
\hline Gas & $17(2.7)$ & $13(3.8)$ & $4(1.4)$ & & $10(10.0)$ & $3(1.6)$ & $0(0)$ & $2(1.0)$ & $2(2.0$ \\
\hline Wood & $110(17.2)$ & $110(32.0)$ & $0(0.0)$ & & $75(75.0)$ & $22(11.3)$ & $13(26.0)$ & $0(0)$ & $0(0)$ \\
\hline Source of drinking & & & & $<0.001$ & & & & & \\
\hline
\end{tabular}




\begin{tabular}{|c|c|c|c|c|c|c|c|c|c|}
\hline water $(n, \%)$ & & & & & & & & & \\
\hline Indoor tap & $243(38.3)$ & $36(10.7)$ & 207 (69.7) & & $3(3.1)$ & 23(11.9) & $10(21.7)$ & $132(67.0)$ & $75(7$ \\
\hline Outdoor tap & $330(52.1)$ & $240(71.2)$ & $90(30.3)$ & & $58(59.8)$ & $151(77.8)$ & $31(67.4)$ & $65(33.0)$ & $25(2$ \\
\hline Borehole & $32(5.1)$ & $32(9.5)$ & $0(0)$ & & $29(29.9)$ & $2(1.0)$ & $1(2.2)$ & $0(0)$ & $0(0)$ \\
\hline River/stream & $29(4.6)$ & $29(8.6)$ & $0(00$ & & $7(7.2)$ & $18(9.3)$ & $4(8.7)$ & $0(0)$ & $0(0)$ \\
\hline $\begin{array}{l}\text { Smoking during } \\
\text { pregnancy }\end{array}$ & & & & 0.667 & & & & & \\
\hline No & $484(74.5)$ & $263(75.1)$ & $221(73.7)$ & & $100(100)$ & $\begin{array}{l}119 \\
(59.5)\end{array}$ & $44(88.0)$ & $\begin{array}{l}152 \\
(76.0)\end{array}$ & 6916 \\
\hline Yes & $166(25.5)$ & $87(24.9)$ & $79(26.3)$ & & $0(0)$ & $81(40.5)$ & $6(12)$ & $48(24)$ & 3113 \\
\hline $\begin{array}{l}\text { Exposure to passive } \\
\text { smoking in the } \\
\text { household (n, \%) }\end{array}$ & & & & $<0.001$ & & & & & \\
\hline No & $379(59.8)$ & $230(67.9)$ & $149(50.5)$ & & $81(81.8)$ & $115(60.5)$ & $34(68.0)$ & $101(51.8)$ & $48(4$ \\
\hline Yes & $255(40.2)$ & $109(32.2)$ & $146(49.5)$ & & $18(18.2)$ & $75(39.5)$ & $16(32.0)$ & $94(48.2)$ & $52(5$ \\
\hline $\begin{array}{l}\text { Perception that air } \\
\text { quality is bad in the } \\
\text { neighbourhood (n, \%) }\end{array}$ & & & & $<0.001$ & & & & & \\
\hline Good & $458(71.6)$ & $293(85.4)$ & $165(55.6)$ & & $100(100)$ & $182(94.3)$ & $11(22)$ & $100(50.8)$ & 6516 \\
\hline $\mathrm{Bad}$ & $159(24.8)$ & $37(10.8)$ & $122(41.1)$ & & $0(0)$ & $5(2.6)$ & $32(64.0)$ & $93(47.2)$ & $29(2$ \\
\hline Don't know & $23(3.6)$ & $13(3.8)$ & $10(3.8)$ & & $0(0)$ & $6(3.1)$ & $7(14.0)$ & $4(2.0)$ & 616.0 \\
\hline $\begin{array}{l}\text { Perception of } \\
\text { environmental } \\
\text { pollution around the } \\
\text { home }(n, \%)\end{array}$ & & & & $<0.001$ & & & & & \\
\hline Yes & $153(24.4)$ & $38(11.1)$ & $115(40.4)$ & & $0(0)$ & $9(4.7)$ & $29(58.0)$ & $91(48.9)$ & $24(2$ \\
\hline No & $475(75.6)$ & $305(88.9)$ & $170(59.7)$ & & $100(100)$ & $184(95.3)$ & $21(42.0)$ & $95(51.1)$ & $75(7$ \\
\hline
\end{tabular}

In all of the study sites, electricity was the predominant source of energy for cooking, except in one of the Indian Ocean study areas (Site 1), where wood was the main source of fuel used for cooking $(\mathrm{p}<0.001)$. The majority of rural women from the Indian Ocean sites reported sourcing their potable drinking water predominantly from communal outdoor taps, however untreated borehole water and water from a river or stream was also reported to be used. The 
majority of women from the Atlantic Ocean sites used potable water from indoor taps (71\%), while only $29 \%$ made use of communal outdoor taps. More participants in the Atlantic Ocean sites were exposed to passive smoking in their households, compared to those from the Indian Ocean sites (50\% versus $30 \%$ ). Overall, only $25.5 \%$ of women reported tobacco smoking during pregnancy, with the women residing in the Atlantic sites reporting a higher prevalence of smoking. Significantly more women from the Atlantic Ocean sites perceived air quality to be inferior in their neighbourhood, and reported environmental pollution around their homes.

\subsection{Arsenic levels in the study population}

3.1.2 Maternal blood arsenic concentrations of all participants - total and by geographical residential positions (along the Indian and the Atlantic Ocean coastlines)

Table 2 shows the maternal AsB concentrations in the total study sample and by their geographical location along the Indian and the Atlantic Ocean coast. In the total study sample, the geometric mean (GM) concentration of As was $0.62 \mu \mathrm{g} / \mathrm{L}(\mathrm{n}=650$; 95\% CI 0.58 0.66), with women residing along the Indian Ocean having significantly higher blood As levels, of GM $0.96 \mu \mathrm{g} / \mathrm{L}(\mathrm{n}=350 ; 95 \%$ CI 0.91-1.02) versus $\mathrm{GM} 0.37 \mu \mathrm{g} / \mathrm{L}(\mathrm{n}=291 ; 95 \%$ CI 0.33-0.41) of women residing along the Atlantic Ocean coast (Wilcoxon rank sum, $\mathrm{p}<0.001$ ).

Table 2 Maternal blood arsenic concentrations - total and by geographical residence

\begin{tabular}{|l|l|l|l|l|}
\hline & $\begin{array}{l}\text { Total } \\
(\mathbf{n = 6 5 0})\end{array}$ & $\begin{array}{l}\text { Indian } \\
\text { Ocean } \\
(\mathbf{n = 3 5 0})\end{array}$ & $\begin{array}{l}\text { Atlantic } \\
(\mathbf{n = 2 9 1})\end{array}$ & $P$ value \\
\hline $\begin{array}{l}\text { Maternal } \\
\text { AsB } \\
\text { levels } \\
(\boldsymbol{\mu g} / \mathbf{L})\end{array}$ & & 0.12 & 0.53 & $<0.001$ \\
\hline Mean & 0.85 & 1.12 & 0.47 & \\
\hline SD & 0.73 & 0.79 & 0.37 & \\
\hline $\begin{array}{l}\text { Geometric } \\
\text { mean }\end{array}$ & 0.62 & 0.96 & $0.33-0.41$ & \\
\hline 95\% CI & $0.58-0.66$ & $0.91-1.02$ & 0.42 & \\
\hline Median & 0.70 & 0.91 & $0.07-3.27$ & \\
\hline Range & $0.07-6.21$ & $0.35-6.21$ & 0.44 & \\
\hline IQR & 0.60 & 0.53 & 0.44 & \\
\hline
\end{tabular}

$\mathrm{p}<0.05$ indicates statistical significance 
3.2.2 Paired arsenic concentrations in maternal and cord blood and maternal urine in subset cohort

The concentrations and descriptive statistics for As levels in paired maternal and umbilical cord blood samples and respective pre-delivery maternal urine samples in the subset cohort residing along the Indian Ocean sites are shown in Table 3 (total for the Indian Ocean study population and by specific study site). The GM of maternal AsB in the total subset cohort was $0.96 \mu \mathrm{g} / \mathrm{L}(\mathrm{n}=350 ; 95 \%$ CI 0.91-1.02), with women residing at Site 1 having the highest GM As concentration of $1.09 \mu \mathrm{g} / \mathrm{L}$ ( $\mathrm{n}=100 ; 95 \%$ CI 1.0-1.20), followed by $0.96 \mu \mathrm{g} / \mathrm{L}$ ( $\mathrm{n}=200$; 95\% CI 0.9-1.03) and 0.75 $\mu \mathrm{g} / \mathrm{L}(\mathrm{n}=49 ; 95 \%$ CI 0.63-0.89) in Site 2 and Site 3, respectively (Kruskal-Wallis rank test, $\mathrm{p}<0.001$ ). The GM concentration of maternal AsU in the total cohort was $12.14 \mu \mathrm{g} / \mathrm{L}(\mathrm{n}=316 ; 95 \%$ CI 10.71-13.76) and the creatinine-corrected GM AsU levels were $14.26 \mu \mathrm{g} / \mathrm{g}$ creatinine ( $\mathrm{n}=316$; $95 \%$ CI 12.64-16.09), with women residing in Site 1 having the highest AsU concentrations.

Table 3 Paired arsenic concentrations in maternal blood, maternal urine and cord blood at delivery in the Indian Ocean subset cohort (total for Indian Ocean study population, and by specific study site)

\begin{tabular}{|l|l|l|l|l|l|}
\hline $\begin{array}{l}\text { Indian Ocean } \\
\text { Sites }\end{array}$ & $\begin{array}{l}\text { Maternal } \\
\text { blood As } \\
(\mu \mathrm{g} / \mathrm{L})\end{array}$ & $\begin{array}{l}\text { Maternal } \\
\text { urine As } \\
(\mu \mathrm{g} / \mathrm{L})\end{array}$ & $\begin{array}{l}\text { Creatinine- } \\
\text { corrected } \\
\text { maternal } \\
\text { urine As }(\mu \mathrm{g} / \mathrm{g} \\
\text { creatinine) }\end{array}$ & $\begin{array}{l}\text { Cord blood As } \\
(\mu \mathrm{g} / \mathrm{L})\end{array}$ \\
\hline Total & Mean & $1.12(\mathrm{n}=350)$ & $21.63(\mathrm{n}=316)$ & $24.12(\mathrm{n}=316)$ & $0.91(\mathrm{n}=317)$ \\
\hline & SD & 0.79 & 26.82 & 30.28 & 0.64 \\
\hline & Median & 0.91 & 12.37 & 15.29 & 0.72 \\
\hline & GM & 0.96 & 12.14 & 14.26 & 0.78 \\
\hline & $\begin{array}{l}95 \% \text { Conf. } \\
\text { Interval }\end{array}$ & $0.91-1.02$ & $10.71-13.76$ & $12.64-16.09$ & $0.74-0.83$ \\
\hline & Min & 0.35 & 0.12 & 0.12 & 0.19 \\
\hline & Max & 6.21 & 215.6 & 278.3 & 5.59 \\
\hline & $90^{\text {th }}$ percentile & 1.91 & 52.67 & 53.83 & 1.53 \\
\hline Site 1 & Mean & $1.22(\mathrm{n}=100)$ & $35.34(\mathrm{n}=80)$ & $32.67(\mathrm{n}=80)$ & $1.01(\mathrm{n}=77)$ \\
\hline & SD & 0.66 & 39.70 & 31.91 & 0.51 \\
\hline
\end{tabular}




\begin{tabular}{|c|c|c|c|c|c|}
\hline & Median & 1.02 & 22.35 & 23.23 & 0.96 \\
\hline & GM & 1.09 & 20.11 & 20.28 & 0.90 \\
\hline & $\begin{array}{l}95 \% \text { Conf. } \\
\text { Interval }\end{array}$ & $1.00-1.20$ & $15.64-25.85$ & $16.01-25.69$ & $0.80-1.01$ \\
\hline & Min & 0.94 & 1.46 & 1.46 & 0.19 \\
\hline & Max & 1.14 & 215.6 & 172.8 & 3.50 \\
\hline & $90^{\text {th }}$ percentile & 1.95 & 88.95 & 80.00 & 1.59 \\
\hline \multirow[t]{8}{*}{ Site 2} & Mean & $1.11(n=200)$ & $17.00(n=187)$ & $20.51(n=188)$ & $1.01(n=191)$ \\
\hline & SD & 0.84 & 17.98 & 23.60 & 0.51 \\
\hline & Median & 0.88 & 11.38 & 14.67 & 0.96 \\
\hline & GM & 0.96 & 10.49 & 12.97 & 0.90 \\
\hline & $\begin{array}{l}\text { 95\% Conf. } \\
\text { Interval }\end{array}$ & $0.90-1.03$ & $8.99-12.25$ & $11.12-15.13$ & $0.80-1.01$ \\
\hline & Min & 0.39 & 0.13 & 0.12 & 0.19 \\
\hline & Max & 6.21 & 113.7 & 232.04 & 3.50 \\
\hline & $90^{\text {th }}$ percentile & 1.82 & 38.61 & 40.79 & 1.59 \\
\hline \multirow[t]{8}{*}{ Site 3} & Mean & $0.93(n=50)$ & $16.93(n=49)$ & $24.00(n=50)$ & $0.82(n=49)$ \\
\hline & SD & 0.82 & 21.30 & 44.67 & 0.56 \\
\hline & Median & 0.68 & 7.91 & 10.16 & 0.68 \\
\hline & GM & 0.75 & 9.31 & 11.61 & 0.71 \\
\hline & $\begin{array}{l}\text { 95\% Conf. } \\
\text { Interval }\end{array}$ & $0.63-0.89$ & $6.74-12.85$ & $8.43-16.00$ & $0.62-0.82$ \\
\hline & Min & 0.35 & 0.75 & 0.75 & 0.29 \\
\hline & Max & 4.18 & 109.5 & 278.31 & 2.72 \\
\hline & $90^{\text {th }}$ percentile & 1.86 & 44.10 & 41.92 & 1.79 \\
\hline
\end{tabular}

The GM level of As in umbilical cord blood in the three Indian Ocean sites (total sample) was $0.78 \mu \mathrm{g} / \mathrm{L}(\mathrm{n}=317 ; 95 \%$ CI $0.74-0.83)$. A linear correlation was found between the $\log$ maternal AsB and the log cord blood As, rho= 0.80, $\mathrm{p}=<0.001$, (Figure 1). 
Figure 1. Arsenic concentration: correlation between log maternal and cord blood samples

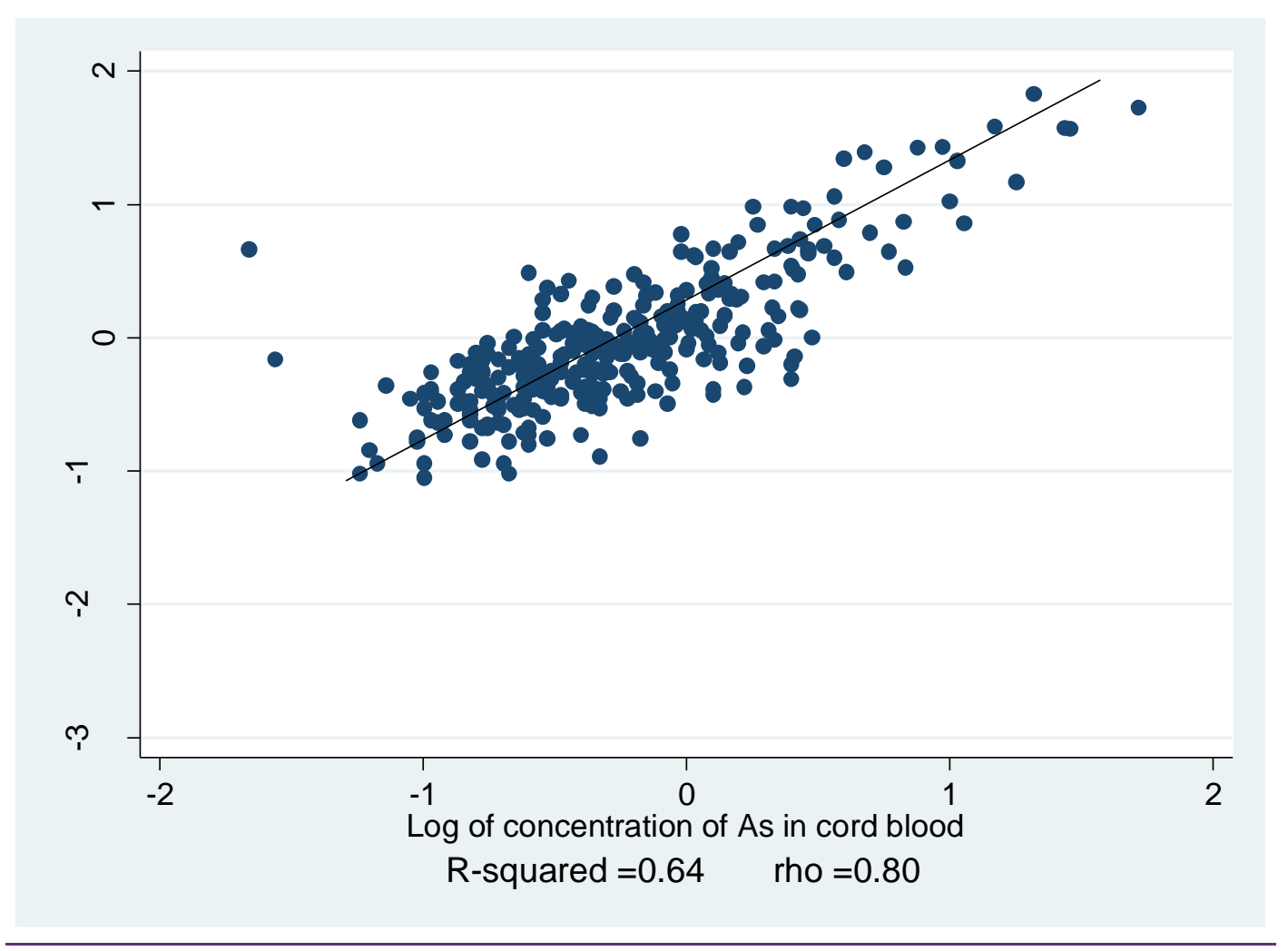

\subsection{Obstetric and newborn parameters}

Table 4 shows differences in obstetric and newborn parameters between the study sites. Maternal height and weight at delivery did not differ between sites. Mothers at the Indian Ocean sites had significantly higher Apgar scores at 5min $(\mathrm{p}<0.01)$. Significant differences in the gestational age between Indian and Atlantic Ocean site populations were found, with newborns from the Indian Ocean sites having a shorter gestational age $(\mathrm{p}<0.001)$. However, no significant differences were observed in birth weight between the sites, and $11 \%$ of infants in the total cohort were considered to be of low birth weight $(<2500 \mathrm{~g})$. Birth length and head circumference differed significantly between the Indian and Atlantic Ocean sites $(\mathrm{p}=0.019$ and $\mathrm{p}<0.001$, respectively). There were no significant differences in sex ratio of newborn between sites, with $50.9 \%$ and $54.9 \%$ being males at the Indian and Atlantic Ocean sites, respectively. Forty nine percent of mothers from the Indian Ocean sites were primiparous, as compared to $36.9 \%$ at the Atlantic Ocean sites $(\mathrm{p}=0.002)$. 
Table 4 Obstetric and newborn parameters

\begin{tabular}{|c|c|c|c|c|}
\hline Characteristic/Parameter & Total $(n=650)$ & $\begin{array}{c}\text { Indian Ocean } \\
(n=350)\end{array}$ & $\begin{array}{l}\text { Atlantic Ocean } \\
(n=300)\end{array}$ & p-value \\
\hline Maternal weight (kg) & $73.4(15.6)$ & $73.2(12.7)$ & $73.7(18.4)$ & 0.501 \\
\hline Maternal height $(\mathrm{cm})$ & $157.8(10.1)$ & $157.7(10.4)$ & $157.9(9.9)$ & 0.126 \\
\hline $\begin{array}{l}\text { Gestational age (weeks) } \\
\text { (mean, SD) }\end{array}$ & $38.2(2.2)$ & $37.8(1.7)$ & $38.7(2.6)$ & $<0.001^{*}$ \\
\hline $\begin{array}{l}\text { Birth weight (g) } \\
\text { (mean, SD) }\end{array}$ & $3063(514.7)$ & $3053.3(494.3)$ & $3075.1(537.5)$ & 0.243 \\
\hline $\begin{array}{l}\text { Birth length }(\mathrm{cm}) \\
\text { (mean, SD) }\end{array}$ & $49.5(3.5)$ & $49.2(3.1)$ & $49.8(3.9)$ & $0.019^{*}$ \\
\hline $\begin{array}{l}\text { Head circumference }(\mathrm{cm}) \\
\text { (mean, SD) }\end{array}$ & $34.7(2.1)$ & $35.1(1.8)$ & $34.4(2.3)$ & $<0.001^{*}$ \\
\hline $\begin{array}{l}\text { Apgar score 1min } \\
\text { (mean, SD) }\end{array}$ & $8.8(7.5)$ & $8.6(1.0)$ & $9.0(10.8)$ & $0.038^{*}$ \\
\hline $\begin{array}{l}\text { Apgar score } 5 \mathrm{~min} \\
\text { (mean, SD) }\end{array}$ & $9.7(0.8)$ & $9.9(0.7)$ & $9.6(0.8)$ & $<0.001^{*}$ \\
\hline Sex (\%male) & 52.8 & 50.9 & 54.9 & 0.320 \\
\hline \multicolumn{5}{|l|}{ Parity $(n, \%)$} \\
\hline 0 & 43.7 & $167(49.1)$ & $106(36.9)$ & \\
\hline $1+$ & 56.3 & $173(50.9)$ & $181(63.1)$ & $0.002 *$ \\
\hline
\end{tabular}

In the bivariate analysis of association between exposures, maternal covariates and infant anthropometry measures at birth, it was found that maternal AsB was significantly negatively correlated with head circumference. In addition, birth weight of infants was positively correlated with maternal age, parity, maternal weight and maternal height. Infant length was also positively correlated with maternal age (see Table 5). There was no significant association between infant anthropometric characteristics and race/ethnicity.

Table 5 Spearman's rank correlation coefficient (p-value) of associations between exposures, maternal covariates and infant anthropometry measures at birth

\begin{tabular}{|l|l|l|l|l|}
\hline \multirow{2}{*}{ Variable } & \multicolumn{2}{|c|}{ Infant anthropometry measures } & \multirow{2}{*}{$\begin{array}{l}\text { Maternal blood As } \\
(\mathbf{c m})\end{array}$} \\
\cline { 2 - 5 }$(\boldsymbol{\mu g} / \mathrm{L})$
\end{tabular}

${ }^{*}$ Indicates significance $(\mathrm{p}<0.05)$ 
An association was also found between maternal and cord AsB (rho=0.707; $\mathrm{p}<0.001)$ and maternal AsB and maternal AsU, both for uncorrected (rho=0.507; $\mathrm{p}<0.001$ ) and creatininecorrected concentrations of As (rho $=0.610 ; \mathrm{p}<0.001)$.

3.4 Univariate and multivariate linear regression analyses - confounders predicting elevated log transformed maternal blood arsenic levels

In univariate analysis, no association between maternal AsB levels and any of the obstetric and neonatal outcomes were found (data not shown). Table 6 represents the association between maternal blood as level and obstetric and neonatal characteristics in the absence of socio-economic, environmental and nutritional variables. This study did not find an association between maternal AsB levels and birth weight, gender and birth length of the baby. However, the lower the gestational age, the higher the maternal AsB $(\beta=-0.054 ; 95 \%$ CI-0.087 to -0.020 ) and mothers who had had at least one child were less likely to have higher AsB compared to those who were primiparous ( $\beta=-0.177 ; 95 \%$ CI- 0.322 to 0.031$)$.

Table 6. Maternal AsB levels $\left(\mu \mathrm{gL}^{-1}\right)$ by obstetric and neonatal outcomes - multivariate analysis

\begin{tabular}{|l|l|l|l|}
\hline Characteristic & B & 95\% Cl & p-value \\
\hline Gestational age & -0.054 & -0.087 to -0.020 & 0.002 \\
\hline Head circumference & 0.044 & 0.007 to 0.081 & 0.019 \\
\hline Parity & & & \\
\hline 0 & Reference & & \\
\hline $1+$ & -0.177 & -0.322 to 0.031 & 0.017 \\
\hline
\end{tabular}


Details of univariate and multivariate analyses are available as Supplementary1. In univariate analyses, according to the marital status reported, single and co-habiting mothers were more likely to have elevated maternal AsB levels, compared to married mothers $(p<0.001, \beta=0.44)$ (Supplementary 1). Conversely, women who were between 20 and 39 years of age were less likely to have higher levels of maternal AsB, than women who were younger than 20 years of age. Coloured women were more likely to have lower AsB levels than African Black women $(\mathrm{p}<0.001, \beta=-0.39)$. In terms of residential area, women from Sites 3 to 5 were shown to have lower AsB levels. Mothers who obtained a secondary level of education were most likely to have lower AsB concentrations ( $\mathrm{p}<0.001, \beta=-0.60)$. Interestingly, residing in informal housing was associated with lower AsB levels $(\mathrm{p}<0.001, \beta=-0.37)$. As expected, using paraffin, gas and wood for cooking predicted higher AsB levels $(p=0.009 ; p=0.021$; $\mathrm{p}<0.001$, respectively). The type of drinking water sources influenced maternal AsB levels. Women who sourced their drinking water from communal outdoor taps (supplying potable clean water) or from boreholes and rivers had higher levels of AsB $(\mathrm{p}<0.001)$ than those who drew their water from indoor taps. Unexpectedly, self reported environmental pollution around the home was associated with significantly lower levels of AsB $(\mathrm{p}=<0.001, \beta=-0.58)$. Maternal AsB levels were higher in the mothers that grew their own vegetables $(p=<0.001$, $\beta=0.60)$ or used pesticides in their gardens $(p=<0.001, \beta=0.47)$. The consumption of leafy and vine vegetables, fruits, dairy products and bottled water on a daily basis during pregnancy, significantly decreased the AsB levels in the mothers $(p=0.031 ; p=0.009$; $\mathrm{p}=<0.001 ; \mathrm{p}=<0.001 ; \mathrm{p}=<0.001$ respectively).

In the final multivariate model, adjustments were made for socio-demographic, nutritional and environmental factors. In terms of marital status, co-habiting with a partner was associated with higher AsB levels $(p=0.007, \beta=0.25$ ). Mothers in the age group 20-29 years were less likely to have lower AsB concentrations, compared to mothers below the age of 20 
years $(p=0.041, \beta=-0.16)$. Coloured mothers were more likely to have elevated AsB levels, when compared to their African Black counterparts $(\mathrm{p}<0.001, \beta=0.37)$. In terms of residential location, mothers residing in the Atlantic Ocean region (Sites 4 and 5) had lower AsB levels than those living in Site 1 of the Indian Ocean region $(p<0.001, \beta=-0.92$ and $p<0.001, \beta=-$ 1.10), respectively. The women that reported environmental pollution around their homes had significantly lower levels of $\mathrm{AsB}(\mathrm{p}=0.004 ; \beta=-0.23)$. Lower levels of $\mathrm{AsB}$ were also found in the mothers who had consumed root vegetables such as potatoes, carrots and sweet potatoes either once a week or daily, before their pregnancy $(p=0.027 ; \beta=-0.57 ; p=0.033 ; \beta=-$ $0.53)$, respectively.

\section{Discussion}

The current study has assessed exposure to As in utero in populations residing along the coastal regions of both the Indian and Atlantic Oceans in South Africa. The study has also examined the potential effects of prenatal exposure to As on birth outcomes and identified possible contributing socio-economic and life style factors. To the best of the authors' knowledge, this is the first study to date investigating these associations in a large cohort of South African women.

When comparing blood concentrations between Indian and Atlantic Ocean sites, the study found highly significant geographical differences in maternal AsB levels $(p<0.001)$, with women residing along the Atlantic Ocean having much lower As levels than Indian Ocean residents. The type of industries found in the two regions could be the main contributing factor to the higher levels of As along the Indian Ocean. Fishing industries, conserved natural habitats and tourism are predominantly found along the Atlantic Ocean, whereas along the Indian Ocean aluminium smelters, coal, titanium and other heavy minerals, granite, 
ferrochrome, paper pulp, woodchips and phosphoric acid production industries are present. A fertilizer plant as well as different types of farming is also prevalent along the Indian Ocean, contributing to higher As levels.

Women residing at Site 1 along the Indian Ocean had significantly higher levels of AsB overall compared to all other sites studied. In this study, the median As levels in maternal $(0.91 \mu \mathrm{g} / \mathrm{l})$ and cord blood $(0.72 \mu \mathrm{g} / \mathrm{l})$ were much lower than those reported from USA (1.4 $\mu \mathrm{g} / \mathrm{l}$ in maternal blood and $2.4 \mu \mathrm{g} / \mathrm{l}$ in cord blood); Argentina $(11 \mu \mathrm{g} / \mathrm{l}$ in maternal blood and $9.0 \mu \mathrm{g} / \mathrm{l}$ in cord blood); Bangladesh $(11.9 \mu \mathrm{g} / \mathrm{l}$ in maternal and $15.7 \mu \mathrm{g} / \mathrm{l}$ in cord blood =) and Taiwan $(6.8 \mu \mathrm{g} / \mathrm{l}$ in maternal blood and $7.9 \mu \mathrm{g} / \mathrm{l}$ in cord blood=) (Claus Henn et al., 2016; Concha et al., 1998; Hall et al., 2007; Soong et al., 1991), but higher than those found in Belgium for the cord blood= $0.56 \mu \mathrm{g} / \mathrm{l}$ (geometric mean) (Remy et al., 2014).

In the subset cohort of women residing along the Indian Ocean, As concentrations were measured in three parameters, namely paired maternal and cord blood and maternal urine. Interestingly, the mean As levels in maternal blood were found to be higher than the As levels in cord blood, which is contrary to the documented literature such as studies in Bangladesh (mean maternal blood $=11.9 \mu \mathrm{g} / \mathrm{l}$, mean cord blood=15.7 $\mu \mathrm{g} / \mathrm{l}$ ) and Bolivia (mean maternal blood=3.81 $\mu \mathrm{g} / \mathrm{l}$, mean cord blood=4.25 $\mu \mathrm{g} / \mathrm{l})$ (Barbieri et al., 2016; Hall et al., 2007) .

The results indicate the potential ability of As to cross the placental barrier, but at a lower rate than other toxic metals such as lead and mercury (Rudge et al., 2009). The linear correlation found between maternal and cord blood $(\mathrm{r}=0.64)$ indicates transfer of As to the foetus, even at considerably low exposure levels, as found in this study. Correlations between maternal and cord blood documented in the literature vary from approximately $r=0.5$ to 0.9 , (Hall et al., 2007; Soong et al., 1991)with higher exposure levels resulting in higher correlation. This mother-to-foetus As transport during pregnancy is of particular concern 
given the detrimental role of As in neurodevelopment (Tofail et al., 2009). The presence of As in cord blood is a serious issue, since As exposure may lead to permanent health effects, some of which may not be apparent or even detectable until much later in childhood or adult life (Farzan et al., 2016). In addition, a number of studies have shown that As retained in the placenta may disrupt its normal function and affect birth outcomes (Laine et al., 2015; Sanders et al., 2014). More research is needed to define the extent of transport of As through the placenta at the various stages of gestation, for different exposure levels.

The urinary results are in line with other studies, as this study has shown significant correlation between As levels in maternal blood and urine (Chen et al., 2009; Hall et al., 2006). Other studies, also investigating low levels of As exposure, have found an association with maternal urine, but only with monomethylated metabolites or blood (Claus Henn et al., 2016; Laine et al., 2015). The higher levels of As in blood and urine in Site 1 are probably due to the release of As from the nearby industries in Mozambique, as this site is located on the border with Mozambique where there is a range of industries, including smelters and mining. Considering that urine concentrations seem to be high for the general population, further investigation is required to identify the likely sources of As.

When an association between As exposure, maternal covariates and infant anthropometry was investigated in this study, there was no effect on birth weight. However, some studies report reduction in birth weight as a result of exposure to As, but no consensus in this respect has been reached as yet (Bermudez et al., 2015; Hu et al., 2015). Nonetheless, the weight of infants was positively correlated with maternal age and parity, while infant length was associated only with maternal age. In addition, this study has found a negative association between maternal AsB levels and head circumference, which is in agreement with a recent study by Henn, et al.(Claus Henn et al., 2016). It is understood that small head circumference for gestational age may result in the reduced brain growth and reduced intellectual ability in 
adults and a variety of antenatal exposures may contribute to the risk (Gale et al., 2004; McElrath et al., 2010).

When examining possible exposure factors, this study found that sourcing drinking water from communal outdoor taps in both geographical areas, and from boreholes and rivers along the Indian Ocean, contributed to higher maternal AsB concentrations. This is an indication that sourcing clean drinking water from communal outdoor taps may introduce contamination, probably from used (previously contained other material, including pesticides, paint, etc.) collection and storage vessels utilized in households (Heeren et al., 2003). This finding will be communicated to health authorities responsible for public health in South Africa. The current study also found that the use of pesticides in gardens and the growing of vegetables contributed to higher maternal As levels. The consumption of meat including chicken did not affect As concentrations, as meat was not locally sourced but purchased from supermarkets. In addition, the daily consumption of vegetables and bottled water offered some protection from As exposure.

Globally, the consumption of fish contaminated with As is considered to be a significant source of human exposure. In univariate analysis, this study found a positive association only between the consumption of tinned fish and AsB levels, but not with the consumption of fresh fish. Fish consumption in South Africa is relatively low compared to global trends, with most of the population preferring livestock and poultry protein. Approximately $80 \%$ of seafood is exported from South Africa, and its population does not traditionally have a seafood eating culture, which is predominantly the domain of middle and upper income groups. In contrast, sardines form the staple diet of a large segment of the South African population (Bosch et al., 2016; South Africa, 2016) 
Using paraffin, gas or wood as a fuel for cooking increased the levels of maternal AsB, possibly due to these fuels being contaminated with As and also to the ability of As to attach to respirable particles and stay in indoor air for many days (Chung et al., 2014).

A limitation of this study is that no measurements were taken of regional environmental As pollution, in an attempt to define sources of exposure, since no data are currently available

\section{Conclusion}

The current study has defined the extent of prenatal exposure to As along coastal regions of South Africa, in a large cohort of women, and established that there are geographical differences in As exposure levels. In addition, birth outcomes (head circumference), source of drinking water, women between the ages of 20-29, self reported pollution and consumption of root vegetables were significantly associated with prenatal exposure to As. Hence, these results can be used as a baseline for further investigations. As reported by Fatoki et al., the African continent is in dire need of assessing As pollution or contamination, and this study has partially contributed to new knowledge in this field, in the region (Fatoki et al., 2013). In terms of public health, one of the predominant concerns is the fact that a large proportion of populations in Africa and other developing countries are of poor socio-economic and health status, which predisposes them to more pronounced toxic effects of As and other contaminants, even at low exposure levels. Our findings indicate that exposure to even low levels of As can impact birth outcomes and are of considerable public health concern.

\section{Acknowledgments}

The authors sincerely thank the Research Council of Norway and the National Research Foundation (NRF), South Africa (Grant 64528); the Arctic Monitoring and Assessment 
Programme (AMAP); and the Norwegian Royal Ministry for Foreign Affairs for financial support.

The authors also express their gratitude to all the study participants, relevant health departments, maternity sections and staff of the hospitals. Special thanks are due to Dr Tahira Kootbodien and Ms Miriam Mogotsi (Medical Research Council, South Africa (SAMRC) for their expert research assistance and to Ms Claudina Nogueira (Board Member of the International Commission on Occupational Health - ICOH - 2012 to 2018) for reviewing this manuscript. 


\section{References}

Abhyankar LN, Jones MR, Guallar E, Navas-Acien A. Arsenic exposure and hypertension: a systematic review. Environ Health Perspect 2012;120:494-500.

Ahmad SA, Sayed MH, Barua S, Khan MH, Faruquee MH, Jalil A et al. Arsenic in drinking water and pregnancy outcomes. Environ Health Perspect 2001;109:629-31.

Ahuja S.:. ArsenicCcontamination of Groundwater Mechanism, Analysis and Remediation 2008.

Bae M, Watanabe C, Inaoka T, Sekiyama M, Sudo N, Bokul MH et al. Arsenic in cooked rice in Bangladesh. Lancet 2002;360:1839-40.

Barbieri FL, Gardon J, Ruiz-Castell M, Paco VP, Muckelbauer R, Casiot C et al. Toxic trace elements in maternal and cord blood and social determinants in a Bolivian mining city. Int $\mathbf{J}$ Environ Health Res 2016;26:158-74.

Bermudez L, Garcia-Vicent C, Lopez J, Torro MI, Lurbe E. Assessment of ten trace elements in umbilical cord blood and maternal blood: association with birth weight. J Transl Med 2015;13:291,015-0654-2.

Bosch AC, O'Neill B, Sigge GO, Kerwath SE, Hoffman LC. Heavy metals in marine fish meat and consumer health: a review. J Sci Food Agric 2016;96:32-48.

CHEN KL, WU HY. Epidemiologic studies on blackfoot disease. 2. A study of source of drinking water in relation to the disease. Taiwan Yi Xue Hui Za Zhi 1962;61:611-8.

Chen Y, Parvez F, Gamble M, Islam T, Ahmed A, Argos M et al. Arsenic exposure at low-tomoderate levels and skin lesions, arsenic metabolism, neurological functions, and biomarkers for respiratory and cardiovascular diseases: review of recent findings from the Health Effects of Arsenic Longitudinal Study (HEALS) in Bangladesh. Toxicol Appl Pharmacol 2009;239:184-92.

Chung JY, Yu SD, Hong YS. Environmental source of arsenic exposure. J Prev Med Public Health 2014;47:253-7.

Claus Henn B, Ettinger AS, Hopkins MR, Jim R, Amarasiriwardena C, Christiani DC et al. Prenatal Arsenic Exposure and Birth Outcomes among a Population Residing near a MiningRelated Superfund Site. Environ Health Perspect 2016;124:1308-15.

Concha G, Vogler G, Lezcano D, Nermell B, Vahter M. Exposure to inorganic arsenic metabolites during early human development. Toxicol Sci 1998;44:185-90.

Croghan C:EP:. Methods for dealing with values below the limit of detection using SAS $2003 ; 2016$.

De Vizcaya-Ruiz A, Barbier O, Ruiz-Ramos R, Cebrian ME. Biomarkers of oxidative stress and damage in human populations exposed to arsenic. Mutat Res 2009;674:85-92.

Dictor MC. Synthese des travaux de R\&D en France (1999-2004) sur la thermatique Arsenic Rapport Final. BRGM 2004;BRGM/RP-53252-FR.

Fangstrom B, Hamadani J, Nermell B, Grander M, Palm B, Vahter M. Impaired arsenic metabolism in children during weaning. Toxicol Appl Pharmacol 2009;239:208-14. 
Farzan SF, Karagas MR, Chen Y. In utero and early life arsenic exposure in relation to longterm health and disease. Toxicol Appl Pharmacol 2013;272:384-90.

Farzan SF, Li Z, Korrick SA, Spiegelman D, Enelow R, Nadeau K et al. Infant Infections and Respiratory Symptoms in Relation to in Utero Arsenic Exposure in a U.S. Cohort. Environ Health Perspect 2016;124:840-7.

Fatoki OS, Ximba Bj, Olujimi OO, Ayanda OS. Arsenic contamination: Africa the missing gap. Asian J Chem 2013;25:9263-9268.

Fei DL, Koestler DC, Li Z, Giambelli C, Sanchez-Mejias A, Gosse JA et al. Association between In Utero arsenic exposure, placental gene expression, and infant birth weight: a US birth cohort study. Environ Health 2013;12:58,069X-12-58.

Gale CR, O'Callaghan FJ, Godfrey KM, Law CM, Martyn CN. Critical periods of brain growth and cognitive function in children. Brain 2004;127:321-9.

Gebel T. Confounding variables in the environmental toxicology of arsenic. Toxicology 2000;144:155-62.

Gilbert-Diamond D, Cottingham KL, Gruber JF, Punshon T, Sayarath V, Gandolfi AJ et al. Rice consumption contributes to arsenic exposure in US women. Proc Natl Acad Sci U S A 2011;108:20656-60.

Golub MS, Macintosh MS, Baumrind N. Developmental and reproductive toxicity of inorganic arsenic: animal studies and human concerns. J Toxicol Environ Health B Crit Rev 1998;1:199-241.

Guan H, Piao F, Zhang X, Li X, Li Q, Xu L et al. Prenatal exposure to arsenic and its effects on fetal development in the general population of Dalian. Biol Trace Elem Res 2012;149:105 .

Hall M, Chen Y, Ahsan H, Slavkovich V, van Geen A, Parvez F et al. Blood arsenic as a biomarker of arsenic exposure: results from a prospective study. Toxicology 2006;225:22533.

Hall M, Gamble M, Slavkovich V, Liu X, Levy D, Cheng Z et al. Determinants of arsenic metabolism: blood arsenic metabolites, plasma folate, cobalamin, and homocysteine concentrations in maternal-newborn pairs. Environ Health Perspect 2007;115:1503-9.

Heeren GA, Tyler J, Mandeya A. Agricultural chemical exposures and birth defects in the Eastern Cape Province, South Africa: a case-control study. Environ Health 2003;2:11.

Hopenhayn C, Ferreccio C, Browning SR, Huang B, Peralta C, Gibb H et al. Arsenic exposure from drinking water and birth weight. Epidemiology 2003;14:593-602.

Hu X, Zheng T, Cheng Y, Holford T, Lin S, Leaderer B et al. Distributions of heavy metals in maternal and cord blood and the association with infant birth weight in China. J Reprod Med 2015;60:21-9.

Huyck KL, Kile ML, Mahiuddin G, Quamruzzaman Q, Rahman M, Breton CV et al. Maternal arsenic exposure associated with low birth weight in Bangladesh. J Occup Environ Med 2007;49:1097-104.

IARC Monograph. Arsenic, Metals, Fibres and Dusts, A review on human carcinogens. IARC 2012;100C. 
Kapaj S, Peterson H, Liber K, Bhattacharya P. Human health effects from chronic arsenic poisoning--a review. J Environ Sci Health A Tox Hazard Subst Environ Eng 2006;41:2399428.

Kempster PL., Silberbauer M., Kuhn A.: Interpretation of drinking water quality guidelines. African Journal Online 2007;33:95-100.

Laine JE, Bailey KA, Rubio-Andrade M, Olshan AF, Smeester L, Drobna Z et al. Maternal arsenic exposure, arsenic methylation efficiency, and birth outcomes in the Biomarkers of Exposure to ARsenic (BEAR) pregnancy cohort in Mexico. Environ Health Perspect 2015;123:186-92.

Marchiset-Ferlay N, Savanovitch C, Sauvant-Rochat MP. What is the best biomarker to assess arsenic exposure via drinking water?. Environ Int 2012;39:150-71.

McElrath TF, Allred EN, Kuban K, Hecht JL, Onderdonk A, O'Shea TM et al. Factors associated with small head circumference at birth among infants born before the 28th week. Am J Obstet Gynecol 2010;203:138.e1,138.e8.

NRC. Arsenic in Drinking Water. NRC 2001;0-309-07629-3.

Rahman A, Vahter M, Ekstrom EC, Rahman M, Golam Mustafa AH, Wahed MA et al. Association of arsenic exposure during pregnancy with fetal loss and infant death: a cohort study in Bangladesh. Am J Epidemiol 2007;165:1389-96.

Rahman A, Vahter M, Smith AH, Nermell B, Yunus M, El Arifeen S et al. Arsenic exposure during pregnancy and size at birth: a prospective cohort study in Bangladesh. Am J Epidemiol 2009a;169:304-12.

Rahman MM, Ng JC, Naidu R. Chronic exposure of arsenic via drinking water and its adverse health impacts on humans. Environ Geochem Health 2009b;31 Suppl 1:189-200.

Remy S, Govarts E, Bruckers L, Paulussen M, Wens B, Hond ED et al. Expression of the sFLT1 gene in cord blood cells is associated to maternal arsenic exposure and decreased birth weight. PLoS One 2014;9:e92677.

Rudge CV, Rollin HB, Nogueira CM, Thomassen Y, Rudge MC, Odland JO. The placenta as a barrier for toxic and essential elements in paired maternal and cord blood samples of South African delivering women. J Environ Monit 2009;11:1322-30.

Sami K., Druzynski AL. Predicted Spatial Distribution of Naturally Occurring Arsenic, Selenium and Uranium in Groundwater in SA-Reconnaissance Survey. WRC 2006;WRC $1236 / 1 / 03$.

Sanders AP, Desrosiers TA, Warren JL, Herring AH, Enright D, Olshan AF et al. Association between arsenic, cadmium, manganese, and lead levels in private wells and birth defects prevalence in North Carolina: a semi-ecologic study. BMC Public Health 2014;14:955,245814-955.

Seber GAF.,Lee AJ.Linear Regression Analysis. John Wiley \& Sons 2003; New Jersey, $2^{\text {nd }}$ Edition.

Smedley PE, Edmunds WM, Pelig-Ba KB. Mobility of arsenic in groundwater in the Obuasi gold-mining area of Ghana: Some implicatiions for human health. Geological Society, Special Publications 1996;113:163-181. 
Soong YK, Tseng R, Liu C, Lin PW. Lead, cadmium, arsenic, and mercury levels in maternal and fetal cord blood. J Formos Med Assoc 1991;90:59-65.

South Africa. A report on the seafish industry in South Africa 2016;31 July 2016.

States JC, Srivastava S, Chen Y, Barchowsky A. Arsenic and cardiovascular disease. Toxicol Sci 2009;107:312-23.

Tabacova S, Baird DD, Balabaeva L, Lolova D, Petrov I. Placental arsenic and cadmium in relation to lipid peroxides and glutathione levels in maternal-infant pairs from a copper smelter area. Placenta 1994;15:873-81.

Thomas S, Arbuckle TE, Fisher M, Fraser WD, Ettinger A, King W. Metals exposure and risk of small-for-gestational age birth in a Canadian birth cohort: The MIREC study. Environ Res 2015;140:430-9.

Tofail F, Vahter M, Hamadani JD, Nermell B, Huda SN, Yunus M et al. Effect of arsenic exposure during pregnancy on infant development at 7 months in rural Matlab, Bangladesh. Environ Health Perspect 2009;117:288-93.

Vahter M, Concha G. Role of metabolism in arsenic toxicity. Pharmacol Toxicol 2001;89:15 .

von Ehrenstein OS, Poddar S, Yuan Y, Mazumder DG, Eskenazi B, Basu A et al. Children's intellectual function in relation to arsenic exposure. Epidemiology 2007;18:44-51. 